\title{
The Promise of Education: The Future
}

\author{
Roberto Escalante Semerena
}

Universities and higher education institutions (HEIs) have always been key actors in society. Their capacity for knowledge production, their constant enquiry into new possibilities of approaching reality and its problems, and their critical thinking have always been highly valued by society. Universities have always accompanied society in its development and will continue doing so. They are a public good and a social right. Society requires a safe space where the freedom to think and freedom of speech exist to reflect on and serve society's needs. This is why society has granted universities the autonomy to organize and govern themselves, with the sole condition being that universities commit to giving back to society the results of the knowledge they generate.

Society is changing rapidly; never before has it experienced such huge technological changes. Within only a few decades, citizens can draw upon technology to enhance their productive capacity, to facilitate communication, to have unprecedented levels of welfare at their disposal, i.e. health care, education, nutrition. Education has not shied away from innovation, and it has embraced these technological benefits. Remote teaching, online education, virtual education and many other possibilities are today a reality allowing millions of people of all ages to have access to knowledge, not only to train themselves for the future but also to continuously enhance current competences through life-long learning. Knowledge has thus become a lifelong companion. The university has always accompanied society, but today it does so more rapidly and efficiently.

Despite all these admirable developments, universities are facing several hurdles. Addressing and discussing them might help us to overcome some of them.

The first one, and one that is extremely important, is pertinence. It is not true that knowledge per se positively affects society and/or nature. In the social and economic

R. Escalante Semerena $(\varangle)$

Association of Universities of Latin America and the Caribbean (UDUAL), Mexico City, Mexico e-mail: roberto.escalante@udual.org 
arena, the current practice known as neoliberalism has produced immense disparities amongst and within societies. More than ever, societies are unequal, and the world is clearly divided between national economies that can amply satisfy the needs of their inhabitants and others whose citizens suffer from a lack of basic health care or who do not receive even the minimum nutritional levels needed. Latin America and the Caribbean, despite their large endowment of resources (see the case of Venezuela), is the most unequal region of the world.

Neoliberalism is a university product, so to speak, as its theoretical aspects were developed within most prestigious academic institutions. It is safe to say that neoliberalism is, and unfortunately will continue to be for some time, extremely pernicious to society.

It is true that it would be hard to imagine any kind of development without the knowledge produced at higher education institutions. At the same time, it is also true that any such knowledge has to benefit the largest sections of society. Today, according to Oxfam, the richest 800 families of the world earn more than the rest of the world combined.

Universities have to be socially oriented, encompassing every sector of society, and setting their priorities clearly. Science has to set itself the task of fighting and overcoming poverty - especially in those communities in which the overwhelming majority are poor.

Science is not, and cannot remain, neutral; it has to be reoriented now. The outputs of scientific production still favour by far the richest sections of society.

Another fundamental challenge higher education institutions have to face is their failure to establish a mutually enriching process of dialogue within societies. It has been said above that development cannot occur without science. However, at the same time, we must recognize that education cannot per se do the whole job. There are many other factors at play and which determine whether development can become a reality - or not. These factors are linked to politics, and that is why HEIs have to learn how to better interact with society. One of the most effective ways of achieving that is to politicize them. And to do that does not mean linking an institution to a particular political party or association; nor does it mean making universities partisan of a particular ideological persuasion. Quite the opposite. What politicizing universities means is to introduce the public concerns into their structural modus operandi. Students, lecturers, researchers must incorporate into their daily tasks such as teaching and research, the urgent needs and pressuring worries of society. Climate change, malnutrition, sanitation, health, education are but a few subjects that have to be present in the daily agenda of those working with knowledge; this will enhance their capacity to put forward feasible solutions.

Relevance and social engagement are primordial. But equally important is having a modern outlook and looking to the future. In the last forty years or so, the world has changed. The use of the Internet has transformed almost every aspect of our life, including education. Many countries are increasingly using digital tools to educate people at all levels. Its impact is so powerful that some scholars have argued that universities could be replaced by digital education; that universities are not as effective as virtual education and are expensive organizations. 
Undoubtedly, the digitalization of life and education are powerful instruments that can help expand the frontiers of knowledge. However, at the same time, we have to be aware that machines are at the service of humans. Thus, what really matters is how we want to use digital tools and which of those instruments are pertinent in the current context.

One example that comes to hand is the present crisis resulting from Covid-19. Remote teaching has allowed the continuation of education provision to millions of students. However, this is true mainly in developed countries where students have access to computers and the Internet. In the low- and middle-income countries, the situation is quite different. Students from poorer parts of society have been excluded because either they do not have computers, or access to the Internet, or both.

Special effort has to be made to incorporate technology into education, including, of course, higher education. However, technology should be at the service of education, of improving university performance in both the social and economic spheres. Let us be modern in order to be more socially oriented.

The 70th anniversary of the International Association of Universities (IAU) represents the propitious occasion to remind ourselves of the need that universities have to be socially oriented in producing knowledge; socially linked to address the real needs of society and also learn from them and to be modern without losing touch with reality. Such a troika must mean maintaining the real sense of education. And that has to be the promise of education. Education, and higher education in particular, is available and is organized to help society and its members and in a more equitable fashion. If higher education does not fulfil that need, it will inevitably lose its raison d'être.

Roberto Escalante Semerena is Secretary-General of the Association of Universities of Latin America and the Caribbean (UDUAL) and Member of the IAU Executive Board. He is a fulltime Professor in the Faculty of Economics at the National Autonomous University of Mexico (UNAM); he received his Bachelor from UNAM and a Master and PhD in Rural Development from the University of London.

Open Access This chapter is licensed under the terms of the Creative Commons Attribution 4.0 International License (http://creativecommons.org/licenses/by/4.0/), which permits use, sharing, adaptation, distribution and reproduction in any medium or format, as long as you give appropriate credit to the original author(s) and the source, provide a link to the Creative Commons license and indicate if changes were made.

The images or other third party material in this chapter are included in the chapter's Creative Commons license, unless indicated otherwise in a credit line to the material. If material is not included in the chapter's Creative Commons license and your intended use is not permitted by statutory regulation or exceeds the permitted use, you will need to obtain permission directly from the copyright holder.

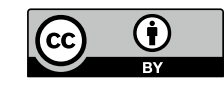

